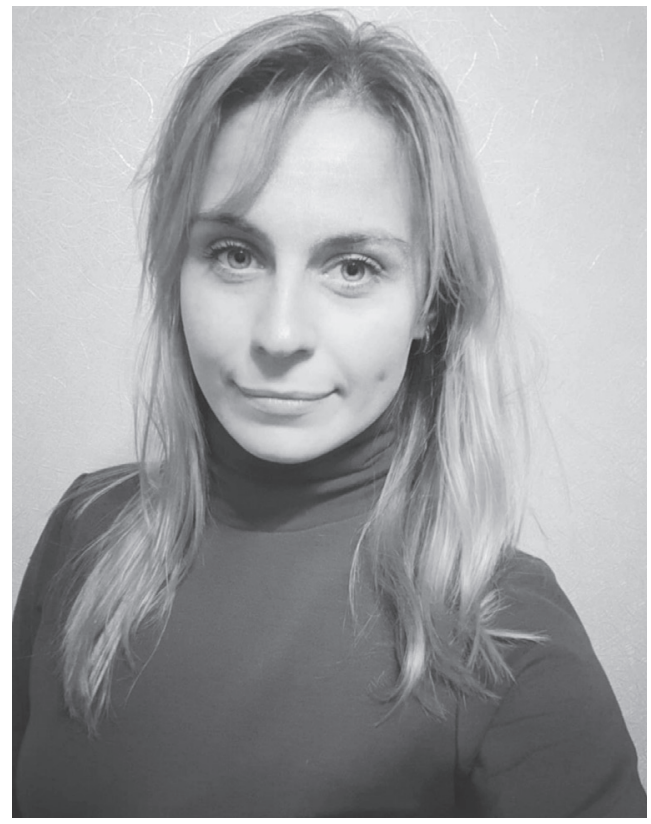

УДК 351.851:005.332.3

https://doi.org/10.32689/2617-2224-

2021-1(26)-72-86

Кузьменко Ганна Олександрівна, аспірант кафедри публічного адміністру вання, Міжрегіональна Академія управління персоналом, 03039, м. Київ, вул. Фрометівська, 2, тел.: +38 (044) 49095 00, e-mail: anna-kuzmenko96@ukr.net, https:// orcid.org/0000-0003-0672-7633

Кузьменко Анна Александровна, аспирант кафедры публичного администрирования, Межрегиональная Академия управления персоналом, 03039, г. Киев, ул. Фрометовская, 2, тел.: +38 (044) 490 95 00, e-mail: anna-kuzmenko96@ukr.net, https://orcid.org/0000-0003-0672-7633

Kuzmenko Hanna Olexandriona,

Postgraduated Student, Department of Public Administration, Interregional Academy of Personnel Management, 03039, Kyiv, Str. Frometivska, 2, tel.: +38 (044) 49095 00, e-mail: anna-kuzmenko96@ukr.net, https://orcid.org/0000-0003-0672-7633

\title{
СОЦІАЛЬНО-ПОЛІТИЧНИЙ МІФ: МІФОТВОРЕННЯ ТА МІФОТВОРЧІСТЬ У ПРИЗМІ СУЧАСНИХ КОМУНІКАТИВНИХ ПРАКТИК
}

Анотація. Проаналізовано міф на основі міждисциплінарного підходу. Це питання не містить точних вказівок стосовно розв'язання актуальних завдань переосмислення ролей міфу у транзитному суспільстві, виокремлення можливостей використання мобілізаційного потенціалу міфу для здійснення позитивних суспільних змін. Тому необхідність окреслення нового розуміння феноменології сучасного міфу, концептуалізації проблемного поля політичного міфу як чинника формування нових якостей політичної свідомості українського суспільства, внесення ясності у питання змістовності, ефективності, моральності, інструментальності міфотворчості у трансформаційному суспільстві обумовлює актуальність теми дослідження.

Динаміка соціокультурних змін на сучасному етапі породжує нові проблеми, пов'язані з кризовими явищами в політичній сфері, посиленні віртуалізацією частини суспільних відносин. Обгрунтовано, що соціальна мі- 
фотворчість є невід’ємною складовою суспільного життя, а найяскравішим iї̈ прикладом стають виборчі кампанії.

Свідомість трансформаційного етапу розвитку українського суспільства є сприятливою основою для змін, але вона особливо схильна до маніпуляцій. Міфологія в соціумі може бути виправданням, відмовкою для утвердження власної бездіяльності. У кризовому суспільстві за умови низької легітимності влади повною мірою розкривається технологічна роль штучних політичних міфів в аспекті маніпуляції суспільною свідомістю.

Отже, образна мова політичної комунікації конструює сакральну політичну реальність способом моделювання уявлення про неї, конституйованого у вигляді значущих фактів-конструктів, релевантного українській політичній культурі “міфотексту”, який читає колективна особистість. Комунікація за допомогою міфу - це модель односторонньої політичної комунікації.

Узагальнено, що соціально-політичний міф дієво структурує бачення нинішнього й майбутнього, але ускладнює усвідомлений політичний вибір.

Ключові слова: соціально-політичний міф, міфотворення, міфотворчість, комунікативні практики, публічне управління.

\section{СОЦИАЛЬНО-ПОЛИТИЧЕСКИЙ МИФ: КОНСТРУРИРОВАНИЕ И МИФОТВОРЧЕСТВО В ПРИЗМЕ СОВРЕМЕННЫХ КОММУНИКАТИВНЫХ ПРАКТИК}

Аннотация. Проанализирован миф на основе междисциплинарного подхода. Данный вопрос не содержит точных указаний относительно решения актуальных задач переосмысления ролей мифа в транзитном обществе, выделение возможностей использования мобилизационного потенциала мифа для осуществления позитивных общественных изменений. Поэтому необходимость определения нового понимания феноменологии современного мифа, концептуализации проблемного поля политического мифа как фактора формирования новых качеств политического сознания украинского общества, внесение ясности в вопрос содержательности, эффективности, нравственности, инструментальности мифотворчества в трансформационном обществе обусловливает актуальность темы исследования.

Динамика социокультурных изменений на современном этапе порождает новые проблемы, связанные с кризисными явлениями в политической сфеpe, усиленные виртуализацией части общественных отношений. Обосновано, что социальное мифотворчество является неотъемлемой составляющей общественной жизни, а самым ярким его примером становятся избирательные кампании.

Сознание украинского общества является благоприятной основой для изменений, но оно особенно подвержено манипуляциям. Мифология в социуме может быть оправданием, отговоркой для утверждения собственной бездеятельности. В кризисном обществе при низкой легитимности власти в 
полной мере раскрывается технологическая роль искусственных политических мифов в аспекте манипуляции общественным сознанием.

Итак, образная речь политической коммуникации конструирует сакральную политическую реальность способом моделирования представления о ней в виде значимых фактов-конструктов, релевантного украинской политической культуре “мифотексту”, который читает коллективная личность. Коммуникация с помощью мифа - это модель односторонней политической коммуникации.

Социально-политический миф действенно структурирует видение настоящего и будущего, но усложняет осознанный политический выбор.

Ключевые слова: социально-политический миф, мифотворение, мифотворчество, коммуникативные практики, публичное управление.

\title{
SOCIO-POLITICAL MYTH: MYTHS MAKING AND MYTH CREATIVITY IN THE PRISM OF MODERN COMMUNICATE PRACTICES
}

\begin{abstract}
The analysis of myth within the political science of the humanities does not contain precise guidelines for solving current problems of rethinking the role of myth in the transit society, highlighting the possibilities of using the mobilizing potential of myth in achieving positive social changes. Therefore, the need to outline a new understanding of the phenomenology of modern myth, conceptualization of the problem field of political myth as a factor in forming new qualities of political consciousness of Ukrainian society, clarifying the content, efficiency, morality, instrumentality of mythmaking in a transformational society determines the relevance of the research topic.

The dynamics of socio-cultural change at the present stage raises new problems associated with the crisis in the political sphere, exacerbated by the virtualization of social relations. Social myth-making is an integral part of public life, and election campaigns are the clearest example of it.

Consciousness of the transformational stage of development of Ukrainian society is a favourable basis for change, but it is particularly inclined to manipulation. Mythology in society can be an excuse, a pretext to assert one's inaction. In a crisis society, given the low legitimacy of power, the technological role of artificial political myths in the aspect of manipulation of public consciousness is fully revealed.

Thus, the figurative language of political communication constructs a sacred political reality by modeling the idea of it, constituted in the form of significant constructive facts, relevant to the Ukrainian political culture 'mythotext', which the collective personality reads. Therefore, communication through myth is a model of one-way political communication.

Socio-political myth effectively structures the vision of the present and the future, but complicates conscious political choices.
\end{abstract}

Keywords: socio-political myth, myth making, myth creativity, modern communicative practices, public management. 
Постановка проблеми. Нині міфи є інструментом, що надає форми комунікативним стратегіям, а політична міфологія - способом осмислення соціальних комунікацій. Міф - це своєрідна форма раціоналізації комунікативних практик.

Серед вітчизняних праць, у яких розвивалася проблематика політичного міфу, слід виділити дослідження Д. Арабаджиєва, В. Артюха, В. Буяна, О. Донченка, С. Кримського, В. Малахова, О. Полисаєва, М. Поповича, Ю. Шайгородського. Однак, на сьогоднішній день відсутня концепція, яка б забезпечувала комплексне уявлення про політичний міф як один із факторів трансформації свідомості сучасного етапу розвитку українського суспільства. До того ж, специфіка феномену політичного міфу зумовлює ситуацію, що його вивчення у вітчизняній науці характеризувалося більше постановою проблеми, ніж її вирішенням.

У рамках даного дослідження важливим $є$ розрізнення природної (еволюційної) тенденції - процесу міфотворення та цілеспрямованого конструювання штучних міфів процесу міфотворчості.

Тому і міфи є різних типів - створені в процесі міфотворчості та через механізми міфотворення. Звісно, більшість міфів, які виникли через міфотворчість, мають чітко визначені суб'єктивні мотиви, а, відтак, формальну міфічну структуру з низьким рівнем енергетики. Через це міф втрачає сакральність. У випадку міфотворення задіяні глибинні енергії колективного і національного несвідомого, що створює можливість занурення людини у сакральний час.
Аналіз останніх досліджень. У працях Р. Барта [1] і Ж. Дерріди [2], що хронологічно тяжіють до другої половини XX ст., можна прослідкувати появу докорінної зміни в розумінні міфу як десакралізованої фрагментарної структури, що не має метанормативної енергетичної наповненості. Жильбер Дюран став першим соціологом, хто приступив до розробки повноцінної "соціології глибин” або “соціології уяви” і досяг на цьому шляху надзвичайно важливих і значних результатів [3]. Соціологія уяви - фундаментальна систематична теорія (гранд-теорія), що дозволяє не тільки врахувати і коректно інтерпретувати значне число фактів і явищ в порівнянні із конвенціональною соціологією, а й виявити додаткові виміри самого соціологічного підходу, який у розширеній i узагальненої версії демонструє нові сторони і властивості, невідомі або ігноровані досі конструкції.

Мета дослідження - проаналізувати процеси створення, значення та змістовні особливості соціально-політичних міфів у призмі сучасних комунікативних практик.

\section{Виклад основного матеріалу.} Соціально-політичний міф можна визначити як образну політико-культурну схему символічної репрезентації взаємовідносин держави та суспільства, що моделює емоційно переконливу картину соціально-політичних відносин.

Інструментальна теорія соціально-політичного міфу розглядає його як засіб маніпулювання суспільною, зокрема масовою, свідомістю. На сучасному етапі, як доведено на основі матеріалів масової культури й полі- 
тичної реклами (Г. Почепцов, Н. Хома), природні процеси міфотворчості замінюються свідомим конструюванням міфу. В умовах дефіциту інформації і упереджених уявлень у суспільстві політичні міфи виконують функцію з формування схематичного аксіоматичного уявлення про соціальні та політичні відносини. Такі уявлення в умовах відсутності рефлексивного мислення роблять людину невразливою до суперечливих повідомлень. Слабкий, самотній, тривожний індивід, як явище сучасного нестабільного світу, потребує залежності та сильних емоційних вражень.

Дослідник С. Манічев у роботі "Міфологія в політичних технологіях" наводить схему конструювання політичного міфу [4]:

1) історія героя міфу триває не в його власному середовищі, а в життєвому просторі виборця;

2) політичний міф має бути драматургічною дією, що викликає емоціональні відчуття, задаючи динаміку життєвих сенсів;

3) міфологічна розповідь має конструюватися за законами наративно-біографічного жанру: відомості про минуле життя героя, рефлексія логіки його життя, "біографічних конструкцій”, прийоми виразності, метафоричність, що дозволяють перевести розповідь в текст із запрограмованим експресивним ефектом;

4) логіка життя героя має співпадати $з$ логікою світосприйняття виборця;

5) політична міфологія висуває до героя певні обов'язкові вимоги: він має бути неординарним - знати щось, чого не знають інші, мати непо- хитну віру в те, заради чого бореться за владу.

За концепцією Г. Шиллера, існують два методи, що забезпечують дієвість маніпулятивних технологій [5, с. 42]: дроблення, локалізація як форма комунікації (передача в новинах великого масиву непов'язаної між собою, фрагментованої інформації, яка діє, як “автоматна черга") та негайність передачі інформації (хибне почуття терміновості, що створює ілюзію надзвичайної важливості предмета інформації, спричинює викривлення дійсного розмежування даних за ступенем важливості). Ці методи послаблюють здатність людей до протидії.

Поряд з тим, набір штучних міфів може бути використано для стратегічної маніпуляції для того, щоб протягом багатьох років у свідомості людей формувати ті цінності, потреби, ідеї, стереотипи, звички, які самі по собі сприяють підтримці вигідного маніпуляторові політичного і економічного ладу.

Для охоплення якнайбільшої кількості людей, міфи в переважній більшості випадків поширюються в процесі масової комунікації, тобто за допомогою ЗМІ (газет, радіо, телебачення, мережі Інтернет). Засоби масової комунікації починають у свідомості людини діяти як першопричина, що наділяє дійсність своїми властивостями. Виникає феномен легко керованого глядацького суспільства із пригніченим критичним мисленням. При чому розвинені засоби масової комунікації ставлять перед собою не стільки завдання повідомити, що відбулося, скільки викликати в аудиторії певну реакцію. 
Це досягається завдяки тому, що часто у програмах новин спочатку йде інформація про наслідки тієї чи іншої події, а лише після цього - про її конкретний зміст.

Потяг до сильного лідера виникає тоді, коли колективне бажання досягає небувалої сили і коли, з іншого боку, всі надії на задоволення цього бажання за допомогою звичних, нормальних засобів не дають результатів.

Героїчний міф - це міф про народження, смерть та воскресіння героя, в якому втілені надії і бажання народу. У такі моменти бажання не лише гостро переживається, але i персоніфікуються.

Політичний міф про героя є не лише семіотичною мовою в комунікаційному просторі будь-якої епохи, але й універсальною архаїчною символічною формою. Коли звичний порядок суспільних відносин, що сприймається як більш чи менш справедливий, руйнується, артикуляція феномену смислу в сфері політики призводить до актуалізації феномену віри в героїчного лідера та сконструйовану сакральну політичну реальність. Лідер-герой перетворюється на знак осмисленої комунікації, адресованої інтерпретатору.

У контексті міфо-героїчного конструювання політичної реальності репрезентація політика пов'язана 3 феноменом легітимності влади. Репрезентація суспільства через будь-якого політичного актора - це певна претензія частини на цілісність, якій не вистачає міфологічного переживання тотожності. Батьківщина або Народ несвідомо трансформуються в героя міфу, а номінований
Герой стає на шлях важких випробувань, перемагає ворога тощо.

Символи героїчного мономіфу презентують для українців ідею політичного порядку, стабільності, прогнозованості політики при небажанні частини громадян брати на себе відповідальність за перспективи майбутнього розвитку подій в країні в умовах тривалої невизначеності.

Символічна система сучасних штучних міфів може розглядатися як мова комунікації між владою і суспільством. Схема комунікативного акту виглядає наступним чином: інформаційне послання влади-адресанта, зашифроване смислонесучим кодом, розшифровується адресатом-соціумом. Влада може не перейматися про діалогічність комунікації, маючи монопольне право транслювати сконструйований “текст”. Так оформлюється подання про легітимну владу в державі.

Сама можливість конструювання віртуальної політики знаходиться в постмодерністському підході до інформації, згідно з яким символічний світ є єдиною релевантною для людини “гіперреальністю", в якій реальність не відрізняється від театральної вистави. Соціальна реальність перетворюється в псевдосвіт, автономний світ образів пропаганди, реклами, тобто суспільство в своїй основі стало глядацьким. У той же час, будь-яка індивідуальна реальність стає соціальною. Комунікація тут можлива за рахунок репрезентації, як одностороннього спектаклю в дусі архаїчного владарювання.

Важливо, що коли сконструйований і вибраний кимось образ стає 
основним зв'язком індивіда зі світом, то в кожному місці, де б він не з'являвся, індивід впізнаватиме цей образ, що несе для нього в собі все. Адже всередині одного і того ж образу без жодного протиріччя можна розташовувати що завгодно.

Створення образів, простір симулякрів, що знаходять віртуальне буття, і що додає особливий онтологічний статус даній реальності - це сучасний комунікативний простір. Демократія, як умовний рефлекс у віртуалізованому світі, не потребує публічного обговорення. Особливо, коли передвиборну кампанію виграють нав'язані думки, а “демонстрація" партійної програми поступається місцем "передбачуваності" запропонованої електорату моделі політичної поведінки.

Міф про героя (архетип українського Котигорошко) залишається центральним у виборчих кампаніях (аспект ситуативної міфотворчості). Імідж героя вибудовується на розумінні базових людських проблем. Герой має: швидко здолати ворога; кардинально змінити ситуацію; швидко вирішити всі проблеми. Незмінними залишаються ідеальні образи влади та лідерів, які передаються від покоління до покоління, хоча все частіше образи реального та ідеального політика суттєво суперечать один одному. Але і на сучасному етапі архетип Героя можна сприймати як певний збірний позитивний образ месії, рятівника, творця чи реформатора. Штучно створене почуття захищеності спричинюе чимало негативних наслідків, перетворюючи індивіда на знеособлену частку колективу.
Існує декілька способів впровадження соціально-політичного міфy [6]:

- пряме впровадження, що передбачає відкритість джерела міфотворчості, але разом з тим не дискредитуе його завдяки природі міфу;

- непряме впровадження, що приховує суб'єкт міфотворчості або дає лише натяк на нього;

- спрямування впливу “від вас" передбачає вказівку на псевдоміфотворця;

- спрямування впливу “не від вас", що запрограмований на чітку констатацію непричетності певного суб'єкта до процесу створення міфу, але, в той же час, не вказує на справжнього міфотворця.

При поширенні соціально-політичного міфу важливу роль відіграє дозування подання інформації. Подання інформації необхідно організувати так, щоб у людини склалось враження, що вона сама її віднайшла або прийшла до певних висновків. Для отримання такого ефекту інформації, фактів необхідно пропонувати менше, ніж людина хоче почути. Як свідчать психологи, інформація засвоюється з четвертого підходу, тому один і той же міф можна запроваджувати в чотири етапи його згадування: не від себе опосередковано, не від себе безпосередньо, від себе ймовірно, від себе прямо [7].

Здійснюючи заміфологізований вибір, людина очікує досягнення міфологічних цілей.

У ході намагання політичних сил нав'язати в “інформаційних війнах" у ході передвиборчих кампаній так звану “свою картину світу” у вигляді міфу політична еліта та інші суб’єк- 
ти міфотворчості готують публіку до сприйняття різних, в тому числі могутніх, символів. Політичний міф стає стимулятором засвоєння громадянами єдиних ідей і цінностей. Однак, часто виникає потреба нейтралізації певних соціально-політичних уявлень. Адже навіть штучні виборчі міфи не саморуйнуються за відсутності потреби виконання ними соціально-організуючої функції в новому політичному контексті.

Серед характерних ознак соціально-політичного міфу можна назвати такі:

1) інтенціональність міфу, його спонукальний характер,

2) абстрактність образів міфологічного повідомлення та намагання їх співвіднести із максимально актуалізованою суспільною тематикою;

3) здатність підміняти рефлективне раціональне осмислення соціально-політичної ситуації ірраціональними когнітивними механізмами віри;

4) багатошаровість значень міфу, що включає: форму-образ, що презентує зміст; головну ідею - концепт, що презентується; зміст як відношення між особистим переживанням i міфологічним дискурсом. Одним із проблемних аспектів такої багатошаровості є двоїстість міфологічних образів, що пов'язані як з потребами групи, так і з емоціями окремої людини.

Серед найбільш поширених сучасних політичних міфів, що інструменталізуються, в тому числі, й через телебачення, можна назвати міф про українське диво, про чарівного рятувальника-визволителя, міф про середній клас, про ринкову економі- ку, про правову державу, демократичний, національний, західний міф (приєднання до західного цивілізаційного простору), народницький міф (народ знає програму дій для всезагального добробуту), міф революційних перетворень.

ЗМІ цілеспрямовано використовують міфоелементи. Деякі матеріали фільтрують, доводяться до аудиторії у деформованому негативному чи гіперболізовано позитивному вигляді, обрамленими яскравими заголовками та ілюстраціями.

Одновимірне сприйняття реальності, що створюють політтехнологи через маніпуляцію символами дуже шкодить стабільному розвитку суспільства. В ідеалі, на нашу думку, найбільший інтерес до формування відносин довіри у системі “влада народ” має вимальовуватися на етапі реалізації стратегічних реформ, а не в періоди виборчих кампаній.

У інформаційну епоху політика характеризується синтезом постсучасності і архаїки. Повернення архаїки спостерігається у суспільному запиті на символічну іпостась зразкового мудреця-гаранта на краю архаїчного хаосу, який магічними здатностями ратифіковує сенс для конституювання цілісного світу. Іноді для зміцнення своєї легітимності використовується “істинний” дискурс героїчного лідерства в просторі одновекторної (у авторитарній) або багатовекторної (для демократичної) смислозмістової політичної комунікації.

Політичний міф “сильної держави” знаходиться в генетичній пам'яті посттоталітарного суспільства, яке у вимірі міфологізованої суспільної 
свідомості схильне сприймати всі економічні проблеми як наслідки демократії.

Періодичну активізацію міфу “сильної держави” в політичній свідомості українського суспільства (1994-2004 pp., 2008-2013 рp., 20142015 рр.) зумовлюють:

1) параліч органів влади, відсутність консенсусу, конфліктність еліт;

2) передвиборчі маніпуляції авторитарними установками масової свідомості з гіперболізацією ефектів останніх (адже авторитарні установки властиві далеко не переважній більшості українського суспільства, навіть в кризові періоди розвитку);

3) залишкові прояви "радянського мислення” в ментальності суспільства, що трансформується;

4) відсутність механізмів ефективної комунікації влади та суспільства, концентрація повноважень окремими органами влади, неможливість попередити узурпацію влади через недієвий механізм стримувань i противаг в системі публічного управління;

5) наявність патримоніальної бюрократії, непотизму.

Ми глибоко переконані, що саме реальне практичне впровадження демократичних цінностей в суспільно-політичній сфері є запорукою високої результативності модернізаційних процесів в Україні. На сучасному етапі суспільного розвитку склалися особливо сприятливі умови для популяризації позитивних символів, стереотипів і міфологем у східних регіонах України, де з часу самоусунення В. Януковича від виконання президентських обов'язків для значної частини населення від- булась руйнація домінантного героїчного міфу.

Сила міфу є своєрідним показником того, чи має народ історичну місію і чи пробила година його національної величі. Нація, народ може мати великий і досить тісний міфологічний простір, однак у ньому завжди є основні, провідні міфи, що несуть в собі найбільше інформаційне, психологічне навантаження. Зазвичай, такі міфи лише звеличують націю, помітно виокремлюючи їі 3-поміж інших, роблячи унікальною, неповторною. Вони існують упродовж тисячоліть, дещо поновлюючись і модифікуючись, та залишаючи при цьому єдину логіку і мету. Низка вітчизняних експертів такі базові суспільні міфи називають "міфами, що підтримують суспільство”, маючи на увазі міф не як вимисел, а як смислоформуюче джерело, ідею або концепцію соціуму, що має всезагальну, надособистісну природу i в якому за допомогою певних символічних форм сформульовані певні ідеальні образи.

2014 р. П. Порошенко запропонував об'єднатися навколо національної ідеї через гасла запропонованої ним Стратегії сталого розвитку 2020 - гідності, свободи, майбутнього. На нашу думку, кореспондує з таким стратегічним баченням дві потреби:

1) об'єднання політичної еліти на шляху здійснення стратегічних реформ;

2) об’єднання еліти 3 нацією для боротьби з агресором.

Дискусія в рамках таких координат важлива. Українському суспільству потрібне чітке розуміння своєї 
позиції у військовому конфлікті на Сході України. Вітчизняні експерти серед конструктивних міфів, що у свідомості українського суспільства можуть трансформуватись у базові, називають:

- міф про порядність, ефективність, доброту і самоцінність пересічного українця (якщо українцю створювати умови, він буде бездоганно працювати і брати участь в політичному житті);

- міф про Україну як Батьківщину, де кожна людина зможе найповніше реалізувати себе;

- національний міф про побудову “України в Україні”.

Такий “бідний” перелік дає зайвий аргумент для констатації потреби цілісної і дієвої гуманітарної та інформаційної державної політики України, що має блискавично реагувати на потреби часу і пропонувати суспільству якісні інформаційні продукти для полегшення процесів ідентифікації у кризові етапи.

Одним з пріоритетів державної політики має бути конструювання системи комплексної протидії міфам руйнівного характеру та активне формування державотворчих політичних міфів, спрямованих на консолідацію нації навколо демократичних цінностей, прав і свобод людини.

Попри штучний та ситуативний характер багатьох міфів, їх предметом все частіше стають політико-економічні реформи, формування нової якості політики. Конструювання позитивних політичних міфів може стати стійкою основою для формування стратегічних концепцій суспільного розвитку України. Можливо, для сучасної України актуальною є потреба формування цілісної концепції політичної міфології, вбудованої в сучасну теорію політики та соціальних змін.

Відомий вітчизняний філософ М. Попович визначає національну міфологію як одну з духовно-творчих сил, котра могла б сприяти подоланню світоглядної кризи в українському суспільстві. Особливе місце в концепції вченого займає "національний політичний міф”, який він вважає потенційно творчим компонентом політичної свідомості [цит. за 7]. Як зазначає А. Цуладзе: “національні міфи - це різновид вічних міфів, вони складають душу народу. Склавшись у період становлення нації, національні міфи супроводжують ïï протягом усієї історії” [8, с. 61]. Haціональна самосвідомість формується на основі міфів і є невіддільною від них. На думку Г. Почепцова, “всі яскраві, з точки зору нації, події наскрізь міфологічні" [9, с. 216].

Однак, коли певні події чи явища, як трипільську культуру чи козацтво, теж підводять під визначення міфу, то така форма погляду на історію, на нашу думку, не є науковою.

Ідеї європейської інтеграції - це, звичайно, позитивні соціально-політичні міфи. Але за умови високого ступеню міфологізації цієї ідеї окремі її частини можуть справляти деструктивний вплив на суспільну свідомість. Наприклад, значне перебільшення окремих елементів міфічного в конструкції міфу “членство в ЄС, що стане миттєвою панацеєю від усіх проблем української економіки та суспільства”. Позиціонуючи європейські цінності, суб'єктам політики та лідерам громадської думки слід пояснюва- 
ти громадянам, що Свропа - це не лише безпроблемне життя, але й відповідальність, регулярна участь у громадському житті та здійсненні різних перетворень.

Більшість міфів, що підтримують в людей почуття безпеки, виконують позитивні функції i, зазвичай, існують на рівні національної ідеології [10].

Цілеспрямована популяризація конкретної версії історії поширюється трьома рівнями суспільно-інформаційного простору:

1) шкільним (школа як надпотужний механізм масової індокринації);

2) емблематичним (наголос на певних фактах із конкретних потрібних моментів, громадська думка, популяризація досягнень нації і збільшення іміджу держави в світі через міфологеми і цілі міфосимвольні комплекси);

3) академічним (реконструкція міфів, культурна, соціальна, психологічна інженерія та інституційне обрамлення актуальних і нових суспільних цінностей).

У базисі національної міфології покладено виключно прості, емоційно переконливі та однозначні істини, що творять колективну ідентичність (безперервність етносу від початків, ушляхетнення власної культурної традиції, культ “пророків” нації та ін.).

Історик I. Бредіс, беручи до уваги неминучість розвитку історичної міфології, похвально відкликається про українців за те, що вони вибрали з національної історії “правильні” епізоди для свого національного позиціювання і пояснення тому факту, що Україна є єдиною республікою (з тих, що утворили в 1922 р. СРСР), яка рухається до демократії: виборний характер гетьмана, культ свободи на Січі, конституційний проект П. Орлика, дисидентський рух у СРСР. За словами історика, поки Росія та інші пострадянські республіки дотримуватимуться національної міфології, в якій протодемократичним началам у їхній історії не приділяється належної уваги, вони залишаться в пастці своїх авторитарних традицій. Україна дає їм приклад того, як можна створити плюралістичну державу, використовуючи відповідні (навіть якщо подеколи в чомусь ідеалізовані) позитивні прецеденти своєї національної історії [11]. Проте, на нашу думку, наразі контроверсійність національної пам'яті українців все ж залишається проблемою, і не всі сторінки історії України трактуються однозначно. В Україні можна констатувати відсутність кордону між науковою (дослідницькою) і науково-популярною історією як наріжним каменем культури пам'яті. У будь-якому разі, на етапі розбудови національної держави надважливим чинником $є$ непротирічна історія нації. Сильні національні самоідентифікаційні міфи є основою цілісності держави, а бажання піддати політичні міфи деструкції часто $є$ намаганням цілеспрямовано штучно делегітимізувати владу та заперечити суверенність держави. У цьому контексті вітчизняні дослідники іноді вживають поняття “кризи міфотворчості”, коли нові міфи не займають місце зруйнованим, таким чином маркуючи наявність вакууму позитивних міфів, що визначають суспільні цінності. 
Історичний досвід певної спільноти через пережиті колективом емоції формує унікальну “колективну пам'ять”. Взагалі, історичні події стають значущими для нащадків, коли вони вкарбовані в структуру національного міфу (історія нації це міф, який створений нею про саму себе). У такому значенні історичні події є “будівельним матеріалом" для національного міфу.

Формування спільних міфо-символьних комплексів спирається на різні чинники (національна система освіти, мас-медіа, кодекси законів) i конституюється у національній культурі (мистецтво, мова). Однак, не варто ігнорувати вірогідність, що в процесі суспільного розвитку навіть корисний міф може опинитися в ситуації, коли він починає гальмувати процес позитивних змін, а, відтак, вимагає модифікації. Тому суб'єкти політики мають допомагати суспільству у створенні нових чи адаптації вже існуючих ідей в умовах динамічних змін. Таким чином, політичні лідери починають боротися зі страхами суспільства (коли наявний вакуум ідей або старі ідеї не придатні обслуговувати нові суспільні відносини) чи попереджувати такі.

Наша точка зору кореспондується 3 думками окремих вітчизняних вчених та експертів про особливу сприйнятливість української суспільної свідомості до кризової міфології. Повсюдність і некритичність використання метафори “антикризовий" у вітчизняному просторі політичних комунікацій (навіть тоді, коли кризи, як такої, де-факто немає) породило небезпечний своїми деструктивними наслідками стійкий соціально-полі- тичний міф про перманентність кризових явищ в Україні.

Соціально-політичний міф має значний потенціал виправляти недоліки ідеологій, однак вірогідність використання популістських гасел в цьому випадку величезна.

За останні півроку Україна прискореним темпом формує свою власну ідентичність - 3 пантеоном мучеників, героїв і зрадників, категоріями “своїх" і “чужих", що дуже чітко викристалізовуються в умовах військових дій.

Функціональне навантаження міфів, що полягає у приховуванні ідеологічного вакууму і підтримки процесу переходу до консолідованої демократії, виявляється універсальним на всіх етапах демократичного транзиту країни. Через слабкість демократичних і ліберальних традицій люди мало довіряють раціональним поясненням складних драматичних змін, які переживають.

Міфотворчість позитивного спрямування дозволяє на деякий час досягнути відносної суспільної рівноваги. На думку Ю. Шайгородського, міф уможливлює обгрунтування як раціональної, так і ірраціональної політики, тому міфічне в активній і пасивній формах проникає в конституції і закони, що стають регуляторами політичного життя. Але, щоб створити той міф, який би беззаперечно об'єднав людей, потрібна величезна концентрація та енергія.

У суспільстві, що трансформується, засилля ілюзій та ірраціональності, хоча і дає певні терапевтичні ефекти, в цілому негативно впливає на стратегічне планування та потенціал сталого демократичного розвит- 
ку, який, в принципі, і є метою трансформацій.

Одне з джерел сучасної тенденції реміфологізації - “напівзнання", у якому символи та реальні події змішуються, позиція людини перед великим масивом інформації є пасивною.

На думку дослідника Б. Галя, протягом століть міфологія залишається, насамперед, технологією перероблення інформації суспільною свідомістю, коли для синтезу світогляду бракує інших засобів [12]. Трансформаційне суспільство викликає гостре відчуття маргінальності і підпорядкованості значних груп населення.

Інтелектуальні кола та політичні еліти України довгий час демонстрували нездатність культивувати нові символи. Це дає підстави стверджувати про неопрацьованість ідеологічних конструкцій суспільної свідомості, що несуть смисли. Поряд з тим, позитивні західноєвропейські міфи, в основному, пов'язувалися у науковій літературі з рекрутуванням у владу середнього класу.

Висновки та перспективи подальших розвідок у цьому напрямі. Специфічною особливістю міфу є те, що він спрощує світ для зручності сприйняття останнього людиною, пояснюе речі і явища зрозумілою мовою, перетворює "хаос у космос". Міфологічне осягнення світу $\epsilon$, перш за все, емоційно-чуттєвим, а не раціональним. Для міфу характерним є ототожнення суб'єктивної i об'єктивної реальності. Міфологічні образи наділяються субстанціональністю, розуміються як реально існуючі. Смисловими одиницями міфо- логічного мислення є не поняття, а колективні уявлення.

Міфи формують в суспільстві певну систему цінностей і диктують відповідні норми поведінки. У цьому сенсі вони виступають в ролі важливих стабілізуючих факторів суспільного життя.

Процеси міфологізації органічно вплетені в різноманітні структури соціального буття, але відбувається це з різною інтенсивністю, в залежності від конкретних умов часу і місця. Найбільш сприятливою для міфологізації сферою є сучасні комунікативні практики.

Процес міфологізації може здійснюватися не тільки шляхом надання ілюзорного статусу реальності вигаданим об'єктам, а й за допомогою: абсолютизації значення випадкових факторів в обгрунтуванні подій; ототожненні випадкового і необхідного в соціальних процесах; додання статусу випадкових необхідним соціальним зв'язкам, виступаючим реальними причинами явищ і процесів. Причому ігнорування діалектичності у взаємодії випадкового і необхідного в соціальному бутті проявляється в тому, що випадковість є формою прояву необхідності, а необхідність реалізується через низку випадкових “відхилень”.

Наслідком багатоманіття гуманітарних текстів на сьогодні є ерозія і нівелювання їхніх значень. У такому контексті актуалізуються механізми, покликані не з'ясовувати значення, а скеровувати суспільну свідомість, коли, швидше, йдеться не про людину, а про способи використання людини в швидкоплинних змодельованих ситуаціях. 
Політична дійсність, окрім об'єктивної, включає і специфічну замкнуту віртуальну реальність, у якій сконструйовані знаки-симулякри, виступають зразками і створюють власний буттєвий світ. Комплексом таких знаків є соціально-політичний міф.

У контексті динаміки демократичного транзиту в Україні міфічні образи, що конструювалися на противагу радянським, тривалий час не спиралися на національні архетипи. За допомогою них так і не було створено єдиної державницької концептуальної картини світу в свідомості суспільства. Характерною для українського суспільства в період трансформацій була антинонімічність між реаліями життя та ідеологією, що нав'язувалась владою.

Україна опинилася на високоміфологізованому етапі свого розвитку в період політичних трансформацій. Трансформаційні процеси в Українській державі здійснюються здебільшого стихійно, під тиском певних груп інтересів або доведених до невдоволення соціальних верств. Коли старі ідеали знаходяться в процесі деструкції, а нові ще не викристалізувалися, зростає попит на просте, емоційно-забарвлене пояснення подій політичного довкілля та місця громадянина в ньому.

Форми інструментального впливу політичних міфів на формування вітчизняного політико-культурного простору відображаються у їхніх технологічних функціях, співвіднесених 3 наступними піками міфотворчості:

1) виборчі кампанії. Виборчі міфи здебільшого позбавлені об'єктивності і є спробою харизматичної мобілі- зації електорату на рік-два під конкретну особистість;

2) хвилі соціально-економічної нестабільності, під час яких міфи використовуються 3 метою посилення легітимізації недостатньо ефективної влади або мобілізації громадян для підтримки непопулярних політичних рішень. Часто міфотворчість має на меті створити інформаційний шум або перманентний ефект очікування "кращих часів, що скоро настануть” та ігнорування об'єктивної реальності;

3) масштабні соціальні протести, пов'язані з кризою ідентичності чи конституційною кризою, у яких проявляється потреба реконструкції соціальної ідентичності.

Тривалий час в Україні державні еліти не займалися позитивною міфотворчістю і навіть дещо гальмували процеси еволюційного природного міфотворення. Наразі динаміка суспільних процесів зумовлює потребу активізації позитивної міфотворчості.

\section{СПИСОК ВИКОРИСТАНИХ ДЖЕРЕЛ}

1. Барт Р. Избранные работы: Семиотика. Поэтика. М.: Прогресс, 1989. $615 \mathrm{c}$.

2. Деррида Ж. Позиции. К.: Д. Л., 1996. $192 \mathrm{c}$.

3. Durand Gilbert. Les Structures anthropologiques de l'imaginaire. Paris: Dunod, 2016. $560 \mathrm{p}$.

4. Маничев C. Мифология в политических технологиях // Общество и политика. СПб.: Изд-во СПб. ун-та, $2000.512 \mathrm{c}$.

5. Шиллер Г. Манипуляторы сознанием. М.: Мысль, 1980. 325 с. 
6. Голосовкер Я. Э. Логика мифа. М.: Наука, 1987. 218 с.

7. Харченко Л. Соціально-гносеологічна природа сучасної міфотворчості: автореф. дис. ... канд. філос. наук: 09.00.03 “Соціальна філософія та філософія історії” / Львівський нац. ун-т ім. Івана Франка. Л., 2004. 18 с.

8. Цуладзе А. Политическая мифология. М.: ЭКСМО: Алгоритм, 2003. $382 \mathrm{c}$.

9. Почепцов Г. Имидж от фараонов до президентов. К.: АДЕФ-Украина. 1997. $328 \mathrm{c}$.

10. Полянська $B$. Символічна політика як система політичних технологій: автореф. дис. ... канд. політ. наук: 23.00.02 “Політичні інститути та процеси”. Дніпропетровськ, 2004. 19 с.

11. Бредіс I. Пострадянський парадокс: демократія в Україні, автократія в Росії // Дзеркало тижня. 2008. № 8 (687).

12. Галь Б. Мифотворчество controlc error [Электронный pecypc]. Peжим доступа: http://dialogs.org.ua/ $\mathrm{ru} /$ project/page12809.html

\section{REFERENCES}

1. Bart R. (1989). Yzbrannue rabotu: Semyotyka. Poetyka [Selected works. Semiotics. Poetics]. Moscow: Progress [in Russian].

2. Derryda Zh. (1996). Pozycyy [Positions]. Kyiv: D. L. [in Russian].

3. Durand G. (2016). Les Structures anthropologiques de l'imaginaire. Paris: Dunod.
4. Manychev S. (2000). Myfologyya v polytycheskyh tehnologyyah [Myth in political technologies]. Saint Petersburg: S.-Peterb. Un-t, 2000 [in Russian].

5. Shyller G. (1980). Manypulyatory soznanyem [Manipylators of mind]. Moscow: Musl [in Russian].

6. Golosovker Ya. (1987). Logyka myfa [Myth logic]. Moscow: Nauka [in Russian].

7. Kharchenko L. (2004). Socialno-gnoseologichna pryroda suchasnoyi mifotvorchosti [Social advantage of modern myth making]. Lviv, Lvivskyj nacionalnyj un-t im. Ivana Franka [in Ukrainian].

8. Czuladze A. (2003). Polytycheskaya myfologyya [Political mythology]. Moscow: Algorytm [in Russian].

9. Pochepczov G. (1997). Imidzh ot faraonov do prezydentov [Image from faraons to presidents]. Kyiv: ADEFUkraina [in Ukrainian].

10. Polyanska V. (2004). Symvolichna polityka yak systema politychnyh tehnologij [Simbolic politics as a system of political technologies]. Dnipropetrovsk [in Ukrainian].

11. Bredis I. (2008). Postradyanskyj paradoks: demokratiya v Ukrayini, avtokratiya v Rosiyi [Post-Soviet paradox: democracy in Ukraine, autocracy in Russia], Dzerkalo tyzhnya Mirror of the Week, 8(687) [in Ukrainian].

12. Gal B. (2013). Myth making. Retrieved from http://dialogs.org.ua/ru/project/page12809.html 